\title{
Perbedaan Kadar C-Reactive Protein Serum Ibu pada Kehamilan Aterm Ketuban Pecah Dini dan Kehamilan Normal
}

\author{
Debby Yolanda ${ }^{1}$, Ariadi $^{2}$, Nur Indrawaty Lipoeto ${ }^{3}$
}

\begin{abstract}
Abstrak
Kehamilan dengan Ketuban Pecah Dini (KPD) masih merupakan masalah penting dalam bidang obstetri, karena berkaitan dengan penyulit atau komplikasi yang dapat meningkatkan morbiditas serta mortalitas maternal dan perinatal. Salah satu faktor risiko KPD yaitu infeksi. C-reactive protein (CRP) merupakan salah satu protein yang meningkat pada saat terjadi infeksi. Tujuan penelitian ini adalah menentukan perbedaan kadar CRP serum ibu pada kehamilan aterm KPD dan normal. Penelitian ini merupakan penelitian observasional dengan rancangan cross sectional. Dilaksanakan di Ruang Kebidanan RSUD Dr. Achmad Mochtar Bukittinggi tahun 2014. Sampel penelitian ini adalah ibu hamil aterm dengan jumlah 60 orang yang diambil dengan Consecutive Sampling, sampel dibagi menjadi 2 kelompok yaitu ibu hamil ketuban pecah dini dan ibu hamil normal. Pemeriksaan kadar CRP dengan menggunakan metode ELISA. Data dianalisa menggunakan t-test independent, dan nilai $p<0.05$ dianggap bermakna secara statistik.

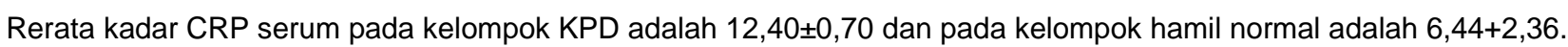
Hasil uji independen t-test menunjukan terdapat perbedaan bermakna rerata kadar CRP serum antara kelompok KPD dengan kelompok kehamilan normal $(p<0,05)$.
\end{abstract}

Kata Kunci: $C$-reactive protein, ketuban pecah dini, kehamilan normal

\section{Abstract}

Pregnancy with prematur rupture of membrane (PROM) still become an important matter in obstetric, as it relates to complication which can increase maternal and perinatal morbidity and mortality. Infection is one of many risk factors of PROM. C-reactive protein is a protein which elevated when there is an infection. The objective of this study was to determine the difference of maternal $C$ - reactive protein serum levels in term pregnancy with prematur rupture of membrane and normal pregnancy. This is an observational study with cross-sectional design. This study takes place in maternity room of RSUD Dr. Achmad Mochtar Bukittinggi in 2014. Samples in this study are 60 aterm pregnant women which have been chosen by consecutive sampling, samples divided with pregnant women with PROM and normal pregnant women. CRP levels measured with ELISA method. Data were analyzed using analysis of independent $t$-test, and $p<0.05$ was considered to be significantly different. CRP serum levels mean in term pregnancy with PROM group is $12.40 \pm 0.70$ and in normal pregnancy group is $6.44 \pm 2.36$. Independent $t$-test analysis showed that there was significant difference of maternal $C$ - reactive protein serum levels between in term pregnancy with PROM and normal pregnancy with $p$ value $<0.05$.

Keywords: $C$ - reactive protein, preterm rupture of membrane, normal pregnancy

Affiliasi penulis: 1. Program Studi S2 Magister Kebidanan FK UNAND (Fakultas Kedokteran Universitas Andalas Padang), 2. Bagian Obstetri dan Gynekologi FK UNAND/RSUP Dr. M Djamil Padang, 3. Bagian IImu Gizi FK UNAND;

Korespondensi: Debby Yolanda, E-mail: debbydiko@gmail.com,Telp: 085266042782

\section{PENDAHULUAN}

Kehamilan dengan Ketuban Pecah Dini (KPD) masih merupakan masalah penting dalam bidang obstetri, karena berkaitan dengan penyulit atau komplikasi yang dapat meningkatkan morbiditas dan 
mortalitas maternal dan perinatal. ${ }^{1}$ KPD mengacu kepada pecahnya membran janin sebelum dimulainya persalinan. Pecahnya membran mengakibatkan persalinan sangat direkomendasikan karena resiko infeksi asenden, sekaligus juga meningkatkan resiko persalinan prematur. KPD yang terjadi pada usia kehamilan aterm, maka persalinan harus dilakukan dengan normal atau induksi dalam 12-24 jam setelah ketuban pecah. ${ }^{2}$

Sekitar $15 \%$ dari seluruh wanita yang hamil akan berkembang menjadi komplikasi yang berkaitan dengan kehamilannya, serta dapat mengancam jiwa ibu dan janin. ${ }^{3}$ Faktor yang berkontribusi terhadap kematian ibu berhubungan dengan komplikasi kehamilan, persalinan dan nifas seperti perdarahan, infeksi, preeklampsi /eklampsi, persalinan macet dan abortus, sementara penyebab utama kematian bayi adalah kelahiran prematur, berat badan lahir rendah, infeksi dan asfiksia. ${ }^{4}$

Pecahnya selaput ketuban dapat terjadi pada setiap usia kehamilan baik pada akhir kehamilan maupun jauh sebelum waktunya melahirkan. Jika ketuban pecah sebelum usia kehamilan 37 minggu disebut KPD preterm dan jika setelah usia kehamilan 37 minggu disebut KPD aterm. ${ }^{5}$ Beberapa penelitian diluar negeri menyatakan bahwa insiden KPD terjadi $8 \%$ pada kehamilan. KPD preterm terjadi sekitar 3\% sedangkan KPD aterm terjadi sekitar 5\%. ${ }^{6}$ Di RSUD Dr. Achmad Mochtar Bukittinggi melaporkan kejadian KPD dari Januari sampai Februari tahun 2014 sebanyak $17,4 \%$ dari seluruh persalinan. 7,8

KPD membutuhkan pengelolaan yang akurat, karena dengan waktu akan meningkatkan morbiditas dan mortalitas ibu dan janin. Hal ini berhubungan dengan semakin lamanya periode laten yaitu lamanya ketuban pecah sampai janin lahir. ${ }^{9}$ Membran janin merupakan barrier terhadap adanya infeksi assenden. Pecahnya membran janin, maka ibu dan janin beresiko untuk terjadi infeksi dan komplikasi lainnya misalnya pada ibu dapat menyebabkan infeksi masa nifas, partus lama, perdarahan post partum bahkan kematian. Sedangkan komplikasi pada janin akibat kasus KPD seperti kelahiran prematur, infeksi perinatal, kompresi tali pusat, solusio plasenta, sindrom distress pada napas bayi baru lahir, perdarahan intraventrikular, serta sepsis neonatorum. ${ }^{2}$

Selama terjadi infeksi produk bakteri seperti lipopolisakarida mengaktifkan makrofag dan sel lain untuk memproduksi dan melepas berbagai sitokin seperti Tumor Necrosis Alfa (TNFa), Interleukin-1(IL-1) dan Interleukin-6 (IL-6). Ketiga sitokin tersebut merupakan sitokin proinflamasi, yang merangsang hati untuk mensintesis dan melepas sejumlah protein plasma seperti protein fase akut antara lain C-Reactive Protein (CRP), yang dapat meningkat 1000 kali, sehingga CRP merupakan salah satu indikator penilaian peradangan atau kerusakan jaringan (nekrosis). ${ }^{10}$

Beberapa studi mengusulkan penggunaan CRP sebagai salah satu parameter untuk membantu menegakan diagnosis dini dari suatu proses infeksi subklinis pada wanita hamil yang mengalami KPD. ${ }^{11}$ Pada saat ini CRP dikenal lebih akurat dibandingkan dengan parameter laboratorium lainnya untuk mendeteksi adanya infeksi atau peradangan, dikarenakan hasilnya sulit dipercaya karena dipengaruhi oleh perubahan hematologi yang fisiologis pada ibu hamil. ${ }^{12}$

\section{METODE}

Ini adalah penelitian observasional dengan rancangan penelitian cross sectional dimana variabel independen dan dependen diteliti dalam waktu bersamaan. Lokasi penelitian adalah Ruang Kebidanan RSUD Dr. Achmad Mochtar Bukittinggi dan di Laboratorium Klinik UPTD Balai Kesehatan Provinsi Sumatera Barat. Data dikumpulkan dari Juni sampai Oktober 2014.

Populasi penelitian ini adalah semua ibu hamil dengan usia kehamilan $\geq 37$ minggu, pada wanita ketuban pecah dini sebagai kelompok studi dan wanita yang tidak mengalami ketuban pecah dini sebagai kelompok kontrol. Subjek penelitian yang dipilih adalah semua populasi yang memenuhi kriteria inklusi dan eksklusi. Kriteria inklusi dalam penelitian ini adalah lbu hamil aterm dengan KPD, normal, janin tunggal, presentasi kepala dan bersedia jadi responden.

Kriteria eksklusi adalah Ibu hamil yang menderita penyakit diabetes mellitus, jantung, hipertensi, Ibu hamil dengan penyakit infeksi sistemik, 
penyakit autoimun, Ibu hamil yang mendapat pengobatan antibiotik sebelumnya dan lbu hamil dengan perdarahan antepartum.

Sebanyak 60 orang responden sebagai sampe penelitian, yang diambil dengan menggunakan metode Consecutive Sampling dimana semua subyek yang datang secara berurutan dan memenuhi kriteria pemilihan dimasukkan dalam penelitian sampai jumlah subyek yang diperlukan terpenuhi. ${ }^{13}$

Serum darah diambil dari responden, sampe dan dianalisis dengan cara kuantitatif menggunakan CRP latex reagent dengan metode ELISA.

Data yang diperoleh diolah secara komputerisasi dan dianalisis dengan uji statistik $t$-test independent untuk menguji perbedaan kadar CRP serum ibu hamil aterm KPD dengan kehamilan normal.

\section{HASIL}

Enam puluh responden yang ikut serta sebagai sampel pada penelitian ini terdiri dari 2 kelompok yaitu 30 orang KPD dan 30 orang dengan kehamilan normal sebagai kontrol.

Tabel 1. Distribusi frekuensi karakteristik responden berdasarkan kelompok usia pada KPD dan kehamilan normal

\begin{tabular}{clllc}
\hline No & Karakteristik & $\mathbf{n}$ & Rerata \pm SD & p \\
\hline 1 & Usia (tahun) & & & \\
& KPD & 30 & $28,27 \pm 5,61$ & 0,101 \\
& NORMAL & 30 & $30,97 \pm 6,86$ & \\
\hline \multirow{2}{*}{2} & Jumlah & & & \\
& Kehamilan & & & \\
& KPD & 30 & $2,03_{ \pm} 1,24$ & 0,114 \\
& NORMAL & 30 & $2,90_{ \pm 2}, 07$ & \\
\hline
\end{tabular}

Tabel 1 menunjukkan bahwa rerata usia responden pada kelompok KPD adalah 28,27 $\pm 5,61$ tahun dan kehamilan normal adalah $31,97 \pm 6,86$ tahun. Hasil uji normalitas pada karakteristik usia menunjukan bahwa data berdistribusi normal dengan nilai $p$ yaitu $0,138(p>0,05)$. Hasil $t$-test pada karakter usia menunjukan tidak terdapat perbedaan bermakna rerata usia antara kelompok KPD dan kehamilan normal $(p=0,101)$.

Karakteristik responden berdasarkan jumlah kehamilan menunjukkan bahwa rerata dan standar deviasi berdasarkan kelompok jumlah kehamilan responden pada kelompok KPD adalah $2,03 \pm 1,24$ dan kehamilan normal adalah 2,90 $\pm 2,07$. Hasil uji normalitas pada karakteristik jumlah kehamilan didapatkan bahwa data berdistribusi tidak normal dengan nilai $p$ yaitu $p=0,001(p<0,05)$. Hasil uji MannWhitney pada karakteristik jumlah kehamilan menyimpulkan bahwa tidak terdapat perbedaan bermakna rerata jumlah kehamilan $(p=0,114)$ antara kelompok KPD dan kehamilan normal. ${ }^{14}$

Tabel 2. Perbedaan kadar rerata CRP serum pada KPD dan kehamilan normal

\begin{tabular}{lccc}
\hline $\begin{array}{c}\text { Kadar CRP } \\
(\mathbf{M g} / \mathbf{L})\end{array}$ & $\mathbf{n}$ & Rerata \pm SD & p \\
\hline KPD & 30 & $12,40 \pm 0,70$ & 0,001 \\
Normal & 30 & $6,44 \pm 2,36$ & \\
\hline
\end{tabular}

Tabel 2 menunjukkan bahwa rerata kadar CRP serum pada kelompok KPD lebih tinggi dari kelompok kehamilan normal. Hasil uji normalitas didapatkan kadar KPD serum berdistribusi normal $p=0,113$ $(p>0,05)$. Hasil uji independen t-test menunjukan terdapat perbedaan bermakna rerata kadar CRP serum antara kelompok KPD dengan kelompok kehamilan normal $(p<0,05)$.

\section{PEMBAHASAN}

Pada penelitian ini diperoleh karakteristik responden berupa usia dan jumlah kehamilan dan perbedaan rerata kadar CRP serum pada kelompok KPD dan kelompok normal.

\section{a. Karakteristik Sampel Penelitian}

Rerata dan standar deviasi berdasarkan kelompok usia responden pada kelompok KPD adalah $28,27 \pm 5,61$ tahun dan kehamilan normal adalah $30,97 \pm 6,86$ tahun. Rerata dan standar deviasi berdasarkan kelompok jumlah kehamilan responden pada kelompok KPD adalah 2,03 $\pm 1,24$ dan kehamilan

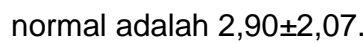

Hasil uji normalitas pada karakteristik usia menunjukan bahwa data berdistribusi normal dengan nilai $p$ yaitu $0,138(p>0,05)$. Hasil uji normalitas pada karakteristik jumlah kehamilan didapatkan bahwa data berdistribusi tidak normal dengan nilai $p$ yaitu $p=0,001$ $(p<0,05)$. Hasil $t$-test pada karakter usia menunjukan tidak terdapat perbedaan bermakna rerata usia antara kelompok KPD dan kehamilan normal $(p=0,101)$. Hasil uji Mann-Whitney pada karakteristik jumlah kehamilan menyimpulkan bahwa tidak terdapat perbedaan 
bermakna rerata jumlah kehamilan $(p=0,114)$ antara kelompok KPD dan kehamilan normal. ${ }^{14}$

Penelitian Tavassoli et al pada tahun 2010 tentang keluaran kehamilan pada kejadian ketuban pecah dini prematur menyatakan hasil yang serupa dengan penelitian ini. Diantara kedua kelompok yang diteliti menghasilkan rentang usia yang tidak terlalu heterogen pada saat masuk rumah sakit, termasuk juga paritas, usia kehamilan pada saat persalinan, dan berat badan lahir diantara dua kelompok. Nilai $p$ juga menyatakan bahwa tidak terdapat hubungan antara karakteristik responden ini dengan kejadian ketuban pecah dini. ${ }^{15}$

Newburn-cook et al pada tahun 2005 melakukan review terhadap beberapa penelitian, untuk menjawab pertanyaan penelitian apakah usia ibu yang lebih tua merupakan faktor risiko terjadinya keluaran kehamilan yang buruk seperti persalinan prematur, KPD dan BBLR. Berdasarkan review terhadap tiga penelitian kohort yang dilakukan, didapatkan hasil yang hampir sama dengan penelitian ini. Hasil dari penelitian tersebut yaitu risiko tertinggi terjadinya persalinan prematur terjadi pada usia ibu $>40$ tahun, dan untuk ketuban pecah dini terdapat peningkatan risiko terjadinya KPD pada ibu hamil dengan usia $\geq 30$ tahun dengan OR $(1,3-1,5) .{ }^{16}$

Hasil penelitian yang berbeda didapatkan oleh Goldman et al pada tahun 2005, dimana mereka meneliti tentang dampak usia ibu terhadap berbagai komplikasi obstetrik pada persalinan salah satunya yaitu KPD. Pada penelitian ini dikelompokkan 3 kelompok usia yaitu kurang dari 35 tahun, 35-39 tahun dan diatas 40 tahun. Faktor perancu yang dihubungkan juga dengan berbagai komplikasi ini termasuk paritas, IMT, tingkat pendidikan, status pernikahan, merokok, dan lain-lain. Analisis penelitian ini yaitu tidak terdapat hubungan yang signifikan antara usia ibu >35 tahun terhadap komplikasi seperti aborsi, hipertensi gestasional preeklamsia, persalinan prematur dan KPD. ${ }^{17}$

\section{b. Perbedaan Rerata Kadar CRP Serum}

Hasil penelitian mendapatkan rerata kadar CRP serum pada kelompok KPD lebih tinggi dari pada kelompok kehamilan normal. Hasil uji normalitas didapatkan kadar KPD serum berdistribusi normal $\mathrm{p}=0,113(\mathrm{p}>0,05)$. Hasil $t$-test menunjukkan terdapat perbedaan bermakna rerata kadar CRP serum antara kelompok KPD dengan kelompok kehamilan normal $(p<0,05)$. Infeksi intrauterin seringkali bersifat kronis dan biasanya tanpa gejala sampai mulai terjadi persalinan atau pecah selaput ketuban. Parameter yang digunakan dalam menegakkan diagnosis infeksi pada saat ini salah satunya penilaian kadar CRP. ${ }^{9}$ Beberapa studi mengusulkan penggunaan CRP sebagai salah satu parameter untuk membantu menegakan diagnosis dini dari suatu proses infeksi subklinis pada wanita hamil yang mengalami ketuban pecah dini. ${ }^{11}$

Respon inflamasi ibu terhadap infeksi bakteri menghasilkan mekanisme potensial lain untuk terjadinya pecahnya selaput ketuban. Selama terjadi infeksi, produk bakteri seperti lipopolisakarida mengaktifkan makrofag dan sel lain untuk menginvasi korionamnion dan desidua untuk mem-produksi dan melepas berbagai sitokin seperti TNFa, II-1 dan II-6. Ketiga sitokin tersebut merupakan sitokin proinflamasi, yang merangsang hati untuk mensintesis dan melepas sejumlah protein plasma seperti protein fase akut antara lain CRP, sehingga CRP merupakan salah satu indikator penilaian peradangan atau kerusakan jaringan (nekrosis). ${ }^{10}$

Beberapa penelitian menunjukkan adanya peningkatan kosentrasi CRP pada ibu hamil yang mengalami infeksi intrauterin. ${ }^{18}$ Penelitian lain juga menunjukkan adanya hubungan erat antara peningkatan serum CRP ibu dan timbulnya korioamnionitis secara histologi pada ketuban pecah dini. Pada penelitian ini, disebutkan bahwa peningkatan kadar sel darah putih dan kadar CRP berhubungan dengan kejadian infeksi early-onset neonatal. Peningkatan kadar CRP sendiri berhubungan dengan kejadian korioamnionitis klinis dan histologis. ${ }^{6}$ Kesamaan penelitian diatas dengan penelitian ini yaitu penggunaan CRP sebagai prediksi korioamnionitis. Namun penelitian diatas juga menggunakan uji sel darah putih, hasil bakteriologis sampel vagina, dan model prediksi pada saat pasien ibu hamil dengan usia gestasi >34 minggu datang ke RS, sedangkan penelitian ini, telah dapat memperlihatkan kegunaan tes CRP sebagai prediksi awal adanya korioamnionitis pada kejadian KPD.

Penelitian Smith et al pada tahun 2012 mempunyai hasil yang berbeda dengan penelitian ini, 
dimana pada evaluasi keluaran dari penelitian tersebut, tidak terdapat perbedaan kadar CRP yang signifikan antara pasien dengan korioamnionitis dengan pasien tanpa korioamnionitis. Namun peningkatkan CRP pada pada penelitian ini secara signifikan dapat digunakan sebagai identifikasi korioamnionitis pada kejadian KPD. ${ }^{19}$

Lee et al pada tahun 2011 juga meneliti keakuratan diagnostik serum CRP ibu untuk menilai funisitis dan sepsis neonatal early-onset pada ibu hamil dengan KPD prematur ataupun matur. Pada penelitian ini pengukuran CRP dilakukan selama 72 jam pada ibu hamil. Kesimpulan penelitian ini yaitu pengukuran CRP pada 72 jam sebelum persalinan merupakan factor independen sebagai prediksi funisitis dan sepsis neonatal early-onset pada ibu hamil dengan prematur KPD maupun aterm KPD. ${ }^{20}$

Sebuah review yang dilakukan oleh Martinez et al pada tahun 2007, review ini menganalis berbagai penelitian yang meneliti penggunaan CRP sebagai prediksi kejadian korioamnionitis pada kejadian KPD prematur. Namun, hasil penelitian ini menyatakan penggunaan CRP sebagai prediksi tunggal untuk mendiagnosis kejadian korioamnionitis pada kejadian KPD tidak terbukti. ${ }^{21}$ Penelitian diatas juga meneliti kegunaan tes CRP sebagai prediksi terhadap dampak infeksi intrauterin pada KPD yaitu korioamnionitis, funisitis, bahkan sepsis neonatal early-onset. Sementara penelitian ini tidak menganalisis kegunaan lebih lanjut dari penggunaan tes CRP sebagai prediksi dampak infeksi intrauterin oleh KPD.

Penelitian oleh Loukovaraa et al pada tahun 2002 juga menganalisis konsentrasi CRP serum sebagai penanda infeksi subklinis pada ibu hamil dengan KPD. Penelitian ini dilakukan karena adanya inflamasi tingkat rendah dapat meningkatkan konsentrasi CRP dalam serum. CRP pada kejadian KPD biasanya berhubungan dengan kejadian infeksi intrauterin. Hasil dari penelitian ini menyimpulkan bahwa adanya peningkatan konsentrasi CRP dalam serum menandakan adanya inflamasi subklinis intrauterine. ${ }^{22}$ Perbedaan dengan penelitian ini yaitu sampel yang diambil oleh Loukovaara yaitu ibu hamil dengan KPD prematur, sedangkan pada penelitian ini ibu hamil aterm dengan KPD.

Beberapa penelitian lain juga menyebutkan bahwa deteksi dan estimasi dengan menggunakan kadar CRP, sitokin, dan fibronektin janin dapat membantu dalam mendiagnosis adanya inflamasi intra amnion. Dinyatakan juga bahwa kadar CRP dapat meningkat jika terdapat infeksi mikroba ataupun tanpa adanya infeksi mikroba. Dalam penelitian ini ditambahkan bahwa interleukin 6 (IL-6) merangsang produksi CRP. Kadar IL-6 akan meningkat sebelum terjadi peningkatan kadar CRP. Kombinasi penggunaan kadar IL-6 dan CRP sebagai prediktor inflamasi intra amnion dinyatakan mempunyai nilai prediksi yang lebih baik. ${ }^{23}$

Adanya beberapa penelitian yang mempunyai hasil yang berbeda dengan teori yang ada dan hasil penelitian ini mungkin juga disebabkan oleh adanya keterbatasan penelitian ini. Namun, memang untuk keterbatasan dari penelitian ini, faktor-faktor lain yang akan menjadi faktor perancu tidak semua faktor dimasukkan ke dalam kriteria ekslusi sampel penelitian ini.

Pada penelitian ini, jika melihat kembali distribusi kadar CRP pada sampel, pada ibu hamil normal, dari 30 orang responden dengan hamil normal, terdapat 8 orang responden yang ditemukan kadar CRP lebih tinggi dari normal. Menurut penelitian Wang dan Hoy pada tahun 2005 yang menyatakan bahwa kadar CRP plasma meningkat seiring dengan pertambahan usia, jadi semakin bertambah usia seseorang maka kadar CRP plasma akan semakin meningkat. $^{23}$

Usia, tekanan darah sistilik dan diastolic, trigliserida, fibrinogen, $\mathrm{BMI}$, insulin dan rasio pinggangpaha berhubungan secara positif dengan kadar CRP, artinya semakin bertambah usia maka kadar CRP juga akan semakin meningkat. ${ }^{24}$ Penelitian Nazmi et al pata tahun 2008 juga menyebutkan bahwa terdapat hubungan yang signifikan antara paritas dengan kadar CRP dalam darah, dinyatakan bahwa ibu yang sudah memiliki 3 atau lebih mempunyai kadar CRP 30\% lebih tinggi dari pada ibu yang belum memiliki anak. ${ }^{25}$ Penelitian Sacks et al pada tahun 2004 yang menyatakan bahwa tidak terdapat hubungan yang signifikan antara paritas dengan peningkatan kadar CRP dalam darah. ${ }^{26}$

Berdasarkan data 8 orang responden yang ditemukan kadar CRP lebih tinggi dari normal didapatkan usia diatas 35 tahun sebanyak 5 orang dan riwayat multipara sebanyak 6 orang responden. 
Penelitian Gurung tahun 2005 menambahkan faktor lain yang mungkin juga menyebabkan peningkatan kadar CRP terlepas dari adanya infeksi yaitu adanya penyakit autoimun ibu seperti rheumatoid arthritis (RA), dan systemic erythematosus. ${ }^{27}$

Fungsi bidan sebagai pemberi asuhan dalam hal ini asuhan antenatal yang bermutu tinggi termasuk deteksi dini komplikasi kehamilan, penanganan pertama kegawatdaruratan kemudian dilanjutkan dengan rujukan. Sehingga, adanya faktor keterlambatan dalam rujukan ke rumah sakit dapat dihindari, penanganan pasien dengan KPD dapat dilakukan lebih cepat dan tepat. Perlu dipahami bahwa bidan merupakan salah satu tenaga kesehatan yang memiliki posisi strategis terutama dalam deteksi dini komplikasi kehamilan, persalinan, dan nifas. Melihat kembali hasil penelitian ini, dengan adanya deteksi dini dan diagnosis yang tepat dari bidan sehubungan dengan faktor risiko ketuban pecah dini dan konseling yang tepat maka proses peradangan dan infeksi mungkin dapat dicegah atau perkembangan inflamasi ataupun infeksi lanjut dapat dikurangi.

\section{KESIMPULAN}

Terdapat perbedaan yang bermakna antara rata-rata kadar CRP serum pada ibu hamil aterm KPD dan kehamilan normal.

\section{DAFTAR PUSTAKA}

1. Prawirohardjo S. Buku acuan pelayanan kesehatan maternal dan neonatal. Edisi ke-3. Jakarta: Yayasan Bina Pustaka; 2002.

2. Caughey A, Robinson J, Norwitz E. Contemporary diagnosis and management of preterm prematur rupture of membranes. Journal of Obstet Gynecol. 2008;1(1):11-22.

3. Feryanto A, Fadlun. Asuhan kebidanan patologis. Jakarta: Salemba Medika; 2011.

4. Kepmenkes RI. Pedoman pelayanan antenatal terpadu Edisi kedua. Jakarta: Direktorat Jenderal Bina Kesehatan Ibu dan Anak Kementrian Kesehatan RI; 2012.

5. Sujiyantini, Mufdillah, Hidayat A. Asuhan patologi kebidanan. Yogyakarta: Nuha Medika; 2009.

6. Popowski T, Goffinet F, Maillard F, Schmitz T, Leroy S, Kayem G. Maternal markers for detedting early onset neonatal infection and chorioamnionitis in cases of prematur rupture of membranans at or after 34 weeks of gestation: a two center prospective study. Biomedcentral Journal. 2011; 11(26):1-9

7. Mulyantoro, Inu. Pola kuman aerob di kanalis servikalis pada ketuban pecah dini. Semarang: Departemen Obstetri dan Ginekologi Fakultas Kedokteran Universitas Diponegoro; 200:11-5.

8. RSUD Achmad Mochtar. Profil Rumah Sakit Umum Daerah Dr. Achmad Mochtar. Bukittinggi: RSAM; 2004.

9. Alamsyah M, Handono B. Ketuban pecah dini pada kehamilan preterm. Edisi ke-1. Bandung: PT Refika Aditama; 2009

10. Baratawidjaja K, Rengganis I. Imunologi dasar. Jakarta: Balai Penerbit Fakultas Kedokteran Universitas Indonesia; 2010.

11. Pitiphat W, Gillman MW, Joshipura KJ, Williams PL, Douglass CW, Rich-Edwards JW. Plasma Creactive protein in eary pregnancy and preterm delivery. American Jurnal of Epidemiology. October 2005; 162(11):1108-13.

12. Dhok AJ, Daf S, Mohod K, Kumar S. Role of early second trimester high sensitivity C-reactive protein for prediction of adverse pregnancy outcome. Bioinformatics Centre MGIMS. July 2011; 13(3):141-4

13. Dahlan S. Besar sampel dan cara pengambilan sampel. Jakarta: Salemba Medika; 2010.

14. Dahlan S. Statistik Untuk Kedokteran dan Kesehatan.Salemba Medika. Jakarta: Salemba Medika; 2010.

15. Tavassoli, F. Ghasemi, M. Mohamad-zade, A. Sharifian J. Survey of pregnancy outcome in preterm prematur rupture of membranes with amniotic fluid index $<5$ and $>5$. Oman Medical Journal. 2010; 25(2):1-6.

16. Newburn-cook CV, Onyskiw JE. Is older maternal age a risk factor for preterm birth and fetal growth restriction? A systematic review. Health for women international Journal. 2005; 26:852-75.

17. Goldman JC, Malone FD, Vidaver J, Ball RH, Nyberg DA, Comstock $\mathrm{CH}$, et al. Impact of maternal age on obstetric outcome. Journal of American College of Obstetricians and 
Gynecologists. 2005; 105:983-90.

18. Lohsoonthom V, Qiu C, Williams MA. Maternal serum C-reactive protein concerations in early pregnancy and subsequent risk of preterm delivery. Clinical Biochemistry Journal. March 2007; 40:5-6.

19. Smith EJ, Muller CL, Sartorius JA, White DR, Maslow AS. C-reactive protein as a prediksi of chorioamnionitis. JAOA. 2012; 112(10):660-4.

20. Lee SY, Park KH, Jeong EH, Oh KJ, Ryu A, Park KU. Relationship between maternal serum Creactive protein, funisitis, and early onset neonatal sepsis. Journal Korean Medicine. 2011; 27:67480.

21. Martinez T, Smith P, Lamont RF. Use of Creactive protein as a prediksi of chorioamnionitis in pretem prelabour rupture of membranes: a systematic review. BJOG Journal. 2007; 1471:796801.

22. Loukovaraa MJ, Alfhtan HV, Kurki MT, Hiilesmaa VK, Anderson SHM. Serum highly sensitive Creactive protein in preterm prematur rupture of membranes. European journal of obstetric and gynecology. 2002; 110(1):26-8.
23. Wang Z, Hoy WE. Population distribution of high sensitivity $C$ - reactive protein values in aboriginal Australians: A comparison with other populations. Journal of Clinical Biochemistry. 2005; 11(016):1-7.

24. Yamada S, Gotoh T, Nakashima Y, Kayaba K, Ishikawa S, Nago N, et al. 2001. Distribution of serum C-reactive protein and its association with atherosclerotic risk factors in a japanese population. Journal of Epidemiology. 2011; 153(12):1183-90.

25. Nazmi A, Oliviera IO, Victora CG. Correlates of Creactive protein levels in young adults: a population-based cohort study of 3827 subjects in Brazil. Brazilian Journal of Medical and Biological Research. 2008; 41(5):357-67.

26. Sacks GP, Seyani L, Lavery S, Trew G. Maternal C-reactive protein levels are raised at 4 weeks gestation. Journal of Human Reproduction. 2004; 19(4):1025-30.

27. Gurung S. Positive C-reactive protein and prematur rupture of membrane. Nepal: National Academy of Medical Sciences; 2005. 